(2014) 22 IIUMLJ 19

\title{
OIL DISCHARGE BY SHIPS AS A FORM OF SECURITY THREAT IN MALAYSIAN PORTS
}

\author{
Abdulkadir O. Abdulrazaq* \\ Sharifah Zubaidah Syed Abdul Kader**
}

\begin{abstract}
The United Nations Convention on the Law of the Sea (UNCLOS) 1982 and some other conventions contain provisions concerning protection of marine environment that enjoy the support of many other regional, national and global institutions. Vessel-sourced pollution is one of the major sources of marine pollution that encompasses accidental as well as, intentional discharge of oil and chemicals, dumping, etc. The Malaysian legal framework requires the consent of the relevant authority for a discharge that is above the quantity allowed. However, despite the fact that there have been numerous regulations on the pollution of the marine waters it appears that pollution by vessels is still on the increase. The legal framework stipulating conditions for discharge of oil at seas is well established in many jurisdictions like Malaysia, however, some of the legal regulations appear to be inadequate, thereby threatening the marine environment and causing irreparable damage.
\end{abstract}

Ph.D (IIUM, Malaysia) LL.M, (Ile-Ife, Nigeria), LL.B (Ilorin, Nigeria), Lecturer, Department of Private and Property Law, Faculty of Law, University of Ilorin, Nigeria. E-mail: Kor181law@gmail.com.

SJD, (Bond, Australia), MCL, LL.B, Associate Professor of Law, Ahmad Ibrahim Kulliyyah of Law, International Islamic University Malaysia. E-mail: shzubaidah@yahoo.com. 
This paper recommends prior consent of the appropriate authority and a stiffer penalty for every discharge of oil by vessels in order to avert hazardous damage.

Keywords: Oil discharge, ships, port security.

\title{
PELEPASAN MINYAK OLEH KAPAL-KAPAL SEBAGAI SATU BENTUK ANCAMAN KESELAMATAN DI PELABUHAN-PELABUHAN MALAYSIA
}

\begin{abstract}
ABSTRAK
United Nations Convention on the Law of the Sea (UNCLOS) 1982 dan beberapa Konvensyen lain membuat peruntukan mengenai perlindungan alam sekitar marin dan ia mendapat sokongan daripada banyak institusi global, nasional dan serantau yang lain. Pencemaran dari kapal adalah salah satu sumber utama pencemaran marin dan ia merangkumi pelepasan minyak yang disengajakan (seperti pelepasan dari tangki pengimbang) dan tidak disengajakan, bahan kimia, bahan buangan, dan sebagainya. Kerangka perundangan Malaysia meletakkan keperluan mendapatkan kebenaran daripada pihak berkuasa berkenaan bagi pelepasan yang melebihi kuantiti yang dibenarkan. Sungguhpun terdapat berbagai peraturan yang mengawal pencemaran marin, pencemaran oleh kapal-kapal dilihat masih meningkat. Kerangka undang-undang yang menetapkan syarat-syarat pelepasan minyak di laut memang wujud di kebanyakan negara seperti Malaysia tetapi beberapa peraturan undang-undang tersebut dilihat tidak mencukupi, sekali gus mengancam alam sekitar di laut dan menyebabkan kerosakan yang tidak dapat dipulihkan kembali terhadap keselamatan manusia. Kertas kerja ini mencadangkan pengenaan syarat memperolehi kebenaran pihak berkuasa berkenaan dan hukuman lebih berat bagi setiap pelepasan minyak oleh kapal-kapal bagi mengelakkan bencana kerosakan.
\end{abstract}

Kata kunci: Pelepasan minyak, kapal, keselamatan, ancaman. 


\section{INTRODUCTION}

The term 'pollution' includes any introduction by man of any substance into the marine environment which results or is likely to result in such deleterious effects to harm marine activities and becomes hazardous to human health. ${ }^{1}$ The tremendous sophistication in appreciating the dangers to the earth's environment and the irreparable damage which may be caused by human activity has resulted in increased effort by governments as well as non-governmental organisations to invoke legal protection for not only the marine environment but the environment in general. The results of these efforts include the ratifications of conventions, protocol, and treaties to tackle the menace of marine pollution. It has been somewhat difficult to address this menace at ports because it relates to human activities that are perhaps responsible for the overall problem.

The 1954 International Convention for the Prevention of Pollution of the Sea by Oil generally prohibits the discharge of oil by ships within 50 miles of land, while the International Convention for the Prevention of Pollution from Ships 1973 is concerned with all forms non-accidental pollution from the ships. Therefore, the 1973 Convention supersedes the 1954 Convention $^{2}$ as it was ratified later. Other conventions in this regard include the International Convention for the Prevention of Pollution from Ships 1973/78 (MARPOL), Rio Declaration 1992 and the United Nations Convention on the Law of the Sea (UNCLOS) 1982. Importantly, the International Maritime Organization (IMO) in the wake of the spill from the Liberian tanker Torrey Canyon which impacted the British coastline, drafted the Intervention Convention in 1975, yet flag states cannot always be relied upon to contain pollution from marine casualties before they adversely affect coastal nations. Before the entry into force of the Intervention Convention in 1975, coastal states had no right to take action against spills outside of their territorial waters, notwithstanding the fact

Article 1(1) (4), UNCLOS 1982.

Malcom N. Shaw, International Law, $3^{\text {rd }}$ Ed. (England: Grotius Publication Limited, 1991), 555. See also Veronica Frank, The European Community and Marine Environmental Protection in the International Law of the Sea, (The Netherland: Martinus Nijhoff Publishers, 2007), 187. 
that the incident might impact their waters or coastlines. The Intervention Convention gives states who are signatories the right to intervene in the high seas if considered necessary to protect their interests after due notification of the flag state.

Furthermore, the 1982 Convention specifically makes provisions concerning protection of the marine environment and interestingly it has the support of many other national, regional and global institutions. It has been asserted that vessel-sourced pollution is one of the major sources of marine pollution that includes intentional discharge of oil (like discharge from ballast tanks), accidental discharge of oil and chemicals, and dumping. ${ }^{3}$ However, despite the fact that there have been numerous regulations on marine pollution, it appears that the menace is still on the increase at a higher degree.

\section{IDEAS POSITED TO TACKLE POLLUTION AT PORTS}

Having highlighted the concept of pollution control in relation to ports, it would be relevant to discuss some ideas posited to tackle such pollution. It is evident that states have vested interests in minimising pollution from ships and the principal means of achieving this objective is through interaction with important international organisations. The International Maritime Organisation (IMO) is an established agency that is charged with the mandate to address this problem. However, developing states in particular are faced with lack of administrative, technical and legal wherewithal to implement the provisions of major conventions. ${ }^{4}$ Developing and developed nations often rely on marine resources and yet lack the capacity to combat and reduce marine pollution that is threatening their marine resources. Thus, in spite of efforts of the international maritime community, oil spillage by ships continues to occur at sea which precipitates pollution of the ports and marine environment as a whole. It is not surprising that at a time when greater efforts are being made to gear-up economic growth and when international trade is

\footnotetext{
$3 \quad$ Sohn L.B and Noyes J.E, Cases and Material on the Law of the Sea (Great Britain: Transnational Publisher, 2004), 684.

$4 \quad$ Ibid, at 715 .
} 
on the increase, the pressure of the increment or economic development is more intense on the ports. Economic development would ordinarily bring about expansion of ports, which will involve land dredging and reclamation that naturally poses environmental hazards to the marine environment and health of the nation. ${ }^{5}$

The International Maritime Organization (IMO) is the sole agency of the United Nations that is devoted to maritime affairs. Since the inception of the IMO in 1958, there have been a comprehensive set of treaty and non-treaty instruments designed to prevent and control marine pollution from vessels. ${ }^{6}$ In order to combat the menace of marine pollution, the IMO has developed strategies and a global programme with the aim of assisting its implementation. These strategies include:

i. Encouraging widest acceptance and implementation of the standards at the global level;

ii. Encouraging the widest practicable standard in matters of marine pollution from ships and maritime safety;

iii. Providing effective legal, technical and scientific cooperation of governments for the prevention of pollution by vessels;

iv. Strengthening the national and regional efforts to prevent and control pollution; and

v. Helping the IMO members, particularly the developing states, to implement these strategies. ${ }^{7}$

Generally speaking, port states apparently have jurisdiction to control the overboard discharges of foreign-flagged ships. The major focus of

\footnotetext{
$5 \quad$ Ibid. See also Frank, at 90.

$6 \quad$ Agustín Blanco-Bazan, "The Environmental UNCLOS and the Work of IMO in the Field of Prevention of Pollution from Vessels," in International Marine Environmental Law: Institutions, Implementation and Innovations, ed. Andree Kirchnerer (Great Britain: Kluwer Law International, 2003), 31.

Ibid. See also Frank, at 90.
} 
environmental enforcement is fundamentally applicable to overboard activities, but as a result of pollution violation convictions, port states have been using their power to control onboard activities on cruise vessels through plea bargain agreements establishing environmental observance programmes. ${ }^{8}$ It has been argued that the only effective way of preserving environmental control policy is to provide a virile incentive for the shipping industry to purposefully regulate shipboard environmental activities. ${ }^{9}$

\section{POLLUTION AS A FORM OF SECURITY THREAT IN MALAYSIAN PORTS}

There is a need for adequate legal regulation to decongest ports' vicinity from the threat of avoidable pollution. The threat of pollution resulting from oil spillage in ports can become alarming when there is insufficient legal framework to combat it, and may have a catastrophic effect on the public and security of states where the legal regime is weak. In order to face these challenges of pollution control that can threaten port security, the Malaysian parliament has passed a series of legislations aimed at the smooth running of ports. However, effectiveness of these legal arrangements in combating the menace in Malaysian ports has yet to be assessed.

Although the primary responsibility of controlling or regulating pollution from ships rests with the flag state which is the country of origin of the ships, some flag states have been unwilling to discharge this onerous duty due to lack of infrastructure, and the flag of convenience which has now become the practice of ship owners. ${ }^{10}$ As such, the exercise

$8 \quad$ Asia N. Wright, "Beyond the Sea and Spector: Reconciling Port and Flag State Control Over Cruise Ship Onboard Environmental Procedures and Policies," Duke Environmental Law \& Policy Forum 18, No. 215 (2007): 216. See also the decision of the court in Spector $v$ Norwegian Cruise Line Ltd (2005) 545 U.S 119, 129.

$9 \quad$ Ibid, 217.

$10 \quad$ See Ho-Sam Bang, "Port State Jurisdiction and Article 218 of the U.N Convention on the Law of the Sea," Journal of Maritime Law \& Commerce 40, No. 2 (2009): 291-292. See also John Hare, "Port State Control: Strong Medicine to Cure a Sick Industry," Journal of 
of powers and jurisdiction by the port state over vessel-sourced pollution has become imperative due to the lackadaisical attitude of flag states.

The issue of pollution threatens the security in ports, in that the aftermath of any inadequacy with regard to discharge by ships calling at ports could seriously affect the populace, taking a cue from the number of ships traversing the Straits of Malacca. ${ }^{11}$ The 1995 pollution incident where there was a dumping of 42 drums of potassium cyanide near a jetty on the island of Pangkor in the Perak State, Malaysia is still remembered. The incident resulted in the death of thousands of fish in three farms, and the total loss was put at RM350,000 (about USD120, 000) as of 1996. The inadequacy of the legal framework was responsible for thwarting the arrest of the offender and the investigation of the case. ${ }^{12}$ Research has shown that while it is not feasible to predetermine the impact of a specific discharge by a ship with any certainty, it is possible to assess the susceptibility to discharge in an area or a particular maritime port. It was argued that sensitivity index mapping of the area where the discharge occurred was considered appropriate at the time of oil pollution, however reservations have been expressed subsequently that such an approach did not take into consideration the actual sensitivity of coastal resources and values for a discharge in coastal areas. ${ }^{13}$

The above is just the tip of an iceberg given the various discharges at ports which threaten the security of a port state. It is certain that laws

International and Comparative Law 26 (1996-1997): 571-572, AdemuniOdeke, “A, Port State Control and U.K Law," Journal of Maritime Law and Commerce 28 (1997): $657 \& 659$.

11 Mohd Azmi bin Mohd Rusli, "The Application of Transit Passage Regime in Straits Used for International Navigation: A Study of the Straits of Malacca and Singapore," Asian Politics and Policy 4, No. 4 (2011): 554.

12 Juita Ramli, "Dumping in Malaysian Seas: An Assessment of the Present Situation vis-à-vis International Legal Regimes," Asian Pacific Journal of Environmental Law 3 (1998): 26.

13 Pourvakhshouri1S.Z, Shattri B.M, Zelina Z.I and Noordin A. "Decision Support System In Oil Spill Management International Archives of Photogrammetry, Remote Sensing, and Spatial Information Sciences," ISPRS Technical Commission II Symposium, Vol. XXXVI - Part 2 Vienna, (12-14 July 2006) 93, accessed April 25, 2012, http://www.isprs.org/ proceedings/XXXVI/part2/pdf/pourvakhshouri.pdf. 
are in place but the adequacy, effectiveness and implementation of the laws are major concerns.

\section{DUMPING OF OIL BY SHIPS}

The legal framework enacted in Malaysia for preventing discharge of oil by foreign ships includes the Merchant Shipping (Oil Pollution) Act, ${ }^{14}$ the Environmental Quality Act, ${ }^{15}$ Environmental Quality (Scheduled Wastes) Regulations, ${ }^{16}$ Exclusive Economic Zone Act ${ }^{17}$ and Continental Shelf Act. ${ }^{18}$ All these Acts refer to the responsibilities and obligations of the public and private sectors over the issue of discharge of oil in the maritime environment. In fact, the Yang Di-Pertuan Agong has the discretion to make regulations concerning measures to be taken in any safety zone for the protection of the marine living resources from harmful agents such as discharge of oil by ships.

The Environmental Quality Act (hereafter referred to as EQA) came into operation on the $15^{\text {th }}$ April, 1975 with the core objective of preventing pollution. This Act was amended in 1996 through the Environmental (Amendment) Act that came into force on $1^{\text {st }}$ August, 1996. The EQA is presently the primary law on pollution control in Malaysia. ${ }^{19}$ A striking feature of the latest enactment is that reference to dumping activities by ships which was hitherto not part of the previous enactments was included. The inclusion of dumping in the latter enactment considers that discharge of oil and waste into the Malaysian territorial seas by ships is an offence except through the conditions specified under section 21 of the Act. The Act provides that:

"No person shall unless licensed, discharge or spill any oil or mixture containing oil into Malaysian waters in

\footnotetext{
$14 \quad$ Merchant Shipping (Oil Pollution) Act.

15 Environmental Quality Act, 1974.

16 Environmental Quality (Scheduled Wastes) Regulations, 1989.

17 Exclusive Economic Zone Act 1984.

18 Continental Shelf Act, 1966.

19 Maizatun Mustafa, Environmental Law in Malaysia, (Netherland:

Wolters Kluwer, 2011), 49.
} 
contravention of the acceptable conditions specified under section 2."20

It was argued that for a ship to be allowed to discharge oil at sea, fulfillment of the conditions specified by the Minister in consultation with the Environmental Quality Council ${ }^{21}$ is a prerequisite. However, a critical examination of the provisions of the Act and other related enactments shows that the Minister has not specified the conditions. ${ }^{22}$ This failure on the part of the relevant authority to specify conditions for discharge is a serious lacuna in the legal framework that may facilitate non compliance with the provisions of the law on the discharge of oil in the Malaysian seas. It is contended that the Department of Environment which is saddled with the enforcement of the law relating to oil spillage and dumping lacks an enforcement mechanism, and thus has to rely on other agencies such as MMEA. ${ }^{23}$

\section{HEAVY SHIPPING ACTIVITY IN THE STRAITS OF MALACCA AND ITS IMPLICATIONS ON THE POLLUTION OF MALAYSIA'S MARITIME DOMAIN}

The importance of the Straits of Malacca with regard to shipping activities in Malaysia cannot be over-emphasised. The Straits of Malacca represent the most convenient route linking East Asia to the Middle East, Africa and Europe. It was also reported that more than $80 \%$ and $90 \%$ of China's and Japan's oil respectively passed through this route. ${ }^{24}$ The presence of heavy ships traversing the Straits is greatly affecting the route ${ }^{25}$ and the

\footnotetext{
$\overline{20} \quad$ See generally sections 27,29 and 34B of the EQA as amended.

$21 \quad$ Maizatun Mustafa, at 49.

22 Juita Ramli, at 34.

23 Kasmin Sutarji, "Enforcing Ship-based Marine Pollution for Cleaner Sea in the Straits of Malacca," Environmental Asia 3 (2010): 62.

24 Stormy-Annika Mildner, Franziska Grob, "Piracy and World Trade: The Economic Cost," in Piracy and Maritime Security, ed. Stefan Mair (Berlin: Germany Institute for International and Security Affairs, 2011), 22.

$25 \quad$ Mohd Hazmi bin Mohd Rusli, "The Application of Transit Passage Regime in Straits Used for International Navigation: A Study of the
} 
narrow nature of the Straits could make it easy for attackers to commandeer a ship. ${ }^{26}$ It is obvious that discharge of waste and oil spillage are characteristic of shipping activities, and because of the large number of ships traversing the Straits of Malacca, the risk of incidents which could cause oil spillage such as accidents is very high. Between 19782003, 888 accidents were reported to have occurred in the Straits of Malacca while 24 accidents were reported from 2005-2010. This means that between 1978-2010, there were 912 shipping accidents that occurred in the Straits of Malacca. From the 2010 Report of the shipping traffic in this route, 74,133 vessels traversed the Straits of Malacca. It was also indicated in the Report that 150,000 vessels are projected to pass through the lane in the year 2020. Shipping traffic in this important route between 2000-2010 is shown below:

Shipping Traffic in the Strait of Malacca, 2000 - 2010 (with the Year 2020 Projection)

\begin{tabular}{ll}
\hline Year & Number of Vessels \\
\hline $\mathbf{2 0 0 0}$ & 55,957 \\
$\mathbf{2 0 0 1}$ & 59,314 \\
$\mathbf{2 0 0 2}$ & 60,034 \\
$\mathbf{2 0 0 3}$ & 62,334 \\
$\mathbf{2 0 0 4}$ & 63,636 \\
$\mathbf{2 0 0 5}$ & 62,621 \\
$\mathbf{2 0 0 6}$ & 65,649 \\
$\mathbf{2 0 0 7}$ & 70,718 \\
$\mathbf{2 0 0 8}$ & 76,381 \\
$\mathbf{2 0 0 9}$ & 71,359 \\
$\mathbf{2 0 1 0}$ & 74,133 \\
$\mathbf{2 0 2 0}$ (Projection) & 150,000 \\
\hline
\end{tabular}

Source: Marine Department of Malaysia (Mohd Hazmi Bin Mohd Rusli, 2012)

Straits of Malacca and Singapore," Asian Politics and Policy 4, No. 4 (2012): 552. See also Douglas Guilfoyle, Shipping Interdiction and Law of the Law, (Cambridge: Cambridge University Press, 2009), 54.

26 Guilfoyle, at 54. See also Mark Valencia, The Proliferation Security Initiative: Making Waves in Asia, (Oxford: Routledge, 2005), 19. 


\section{HIGHLIGHTS OF THE LEGAL FRAMEWORK ON LICENSE FOR DUMPING OIL}

The Malaysian Environmental Quality Act raises the question of license under part III, section 11 as a prerequisite for the discharge of oil into Malaysian sea. This presupposes that a ship is not allowed to discharge oil into Malaysian waters except when a license in respect thereof has been granted by the licensing authority. According to the Act, the licensing authority in this regard by virtue of section 10 is the Director General. A particular clause in this legal regime is the reference to a maximum allowable limit of pollution a person or a ship may discharge into the environment without the consent of the licensing authority. ${ }^{27}$ There appears to be a problem with this provision, as in the first place, a person or ship should not be allowed to discharge any quantity of waste into the water or sea except with the consent and approval of the relevant authority. The stipulation of a particular quantity means that if a discharge is not up to the maximum allowable limit, the consent of the minister or other authority may be dispensed with before a discharge takes place. The provision is silent where for instance, the discharge is being carried out in a piece meal manner and each discharge is not up to the minimum quantity specified under the Act. For this reason, it is recommended that discharge of whatever quantity into the sea should be with the consent of the appropriate authority who shall in turn determine the quantity to be discharged and the appropriate sum to be paid, anything short of this may render the Act ineffective as regards the prohibition of discharging oil. Also, the authority vested with the power to inspect will have to apply necessary measures in order to control the hazardous impact of the substance discharged. It is interesting to note that the amount to be paid by the ship owners to the authority for the discharge will be used to meek the expenses incurred to clear such discharge, and this will avert the side effects of such discharge on the port and marine environment in general.

It also merits mention that where a licensed ship has failed to observe the terms and conditions for the discharge of oil into the marine environment in Malaysia, the maximum liability is RM25,000 (over

$27 \quad$ Section 11 (c), EQA. 
USD8,300.00) or imprisonment for a period not exceeding 2 years or both, and RM1,000 (About USD330) every day upon the continuation of the offence after notice had been served. ${ }^{28}$ Apart from the fact that the maximum penalty may not be adequate if compared with what is obtainable in neighbouring jurisdictions like Singapore where the maximum penalty is USD500,000.00. ${ }^{29}$ The Singapore Prevention of Pollution at the Sea also empowers the Maritime and Port Authority (MPA) to take preventive measures to prevent pollution, including denying entry or detaining ships. Therefore, there is a need to modify this provision of the law, as it appears that monetary liability could sometimes fail to serve as a deterrence for the continuation of an offence. It is therefore recommended that in the case of continuation of the offence after serving notice on the offending ship through the company or the owner, the subsequent line of action should be to commence criminal prosecution against the offender or to deny access to such ship by the Malaysian Port Authority. This prosecution may be commenced by the environmental department in consultation with the office of the Attorney-General and the offending ship may be detained pending the outcome of the criminal prosecution. Through this measure, owners of ships could be made wary of their activities with regard to wanton discharge, as they would not want to run at a loss which could result from the detention of their ships.

Furthermore, Malaysia as a sovereign state has unfettered rights to exploit her natural resources and protect the marine environment through necessary policies. It is on this premise that the Exclusive Economic Zone ${ }^{30}$ prohibits discharge or escape of oil from ships resulting in damage or pollution of the marine environment, and where such occurs within the exclusive economic zone of Malaysia, the owner and master of the ship may be made liable jointly and severally. The liability of the owner and master of the ship is extended to compensation for the damaged

\footnotetext{
$28 \quad$ Section 16.

29 See for example, the Prevention of Pollution at the Sea Act, 1990. This Act came into force on $1^{\text {st }}$ February, 1991. This is an Act to give effect to the International Convention for the Prevention of Pollution from Ships 1973 as modified and added to by the Protocol of 1978 , and to other international agreements relating to the prevention, reduction and control of pollution of the sea and pollution from ships, etc. The Exclusive Economic Zone Act, 1984.
} 
property. Importantly, claims in this respect may be filed before the Session Court or a Magistrate of the First Class Grade at the High Court in Malaysia, depending on which of these courts has jurisdiction over the amount claimed. ${ }^{31}$

It is observed that the EQA is silent on the main concept of discharge, placing, deposit or disposal of pollutant substances by ships. Although these words may be interpreted to include dumping activities, there is a need for the Act to be more precise with regard to the limitation and extent of their application vis-à-vis pollution within the Malaysian Exclusive Economic Zone. Therefore, further subsidiary legislation in this regard may be necessary in order to combat marine pollution by ships. ${ }^{32}$ It may be argued also that although the Act addresses the issue of dumping, the provisions appear to be insufficient or imprecise for effective management of dumping at sea. ${ }^{33}$ Hence, for Malaysia to achieve the targeted goal on prevention of discharge by ships there is need for a "Port Reception Facility" possibly near the ports, in order to attempt avert discharge at sea. ${ }^{34}$

Port Reception Facility is a type of palliative measure provided by an international shipping port to collect oily mixtures, residues and garbage that are generated by sea going ships. Where such arrangements are in place at a port, they must be such that the receiving process can be performed as quickly as possible to avert undue delay of ships, and must be of sufficient capacity to receive the dirt discharged. ${ }^{35}$ The IMO has encouraged state parties to provide good reception facilities in order to achieve effective implementation of MARPOL on prohibition of discharge of oil at sea by ships. Therefore, the acceptance of the 1996 Protocol to the London Convention in this respect will be of immense assistance to realise the benefit of contracting states, and to avoid security

\footnotetext{
$31 \quad$ Ibid, Section 40(4). See also Maizatun Mustafa, at 225.

32 Juita Ramli, at 35.

$33 \quad$ Ibid, 39 .

34 This proposition is the main objective of the London Convention and the 1996 Protocol.

$35 \quad$ See "What is Port Reception Facility?," Marine Insight, accessed December 26, 2012, http://www.marineinsight.com/marine/marine-news/ featured/what-is-port-reception-facility/
} 
threats likely to be the resulting effect of wanton discharge of oil in Malaysian waters.

\section{OBSERVATIONS ON THE MMEA ACT ON THE DISCHARGE FROM SHIPS}

Prior to the establishment of the Malaysian Maritime Enforcement Agency (MMEA), there were about eight agencies in existence enforcing over 40 federal laws, agreements and regulations in Malaysia. ${ }^{36}$ One of the main objectives for setting up the MMEA was to resolve the overlap between the security agencies with regard to operations, functions and jurisdictions. ${ }^{37}$ The purpose of the Malaysian parliament in promulgating the MMEA Act could be gleaned from the long title to this legislation which basically addresses the enforcement in the event of any breach of law in the use of maritime zone. The following short comings are noteworthy in the Act:

1. The Act is more concerned about the aftermath of failure to observe maritime ethics, while being silent on any preventive measure to be put in place at ports to thwart any act that can expose ports and the nation to threats of pollution.

2. The Act deals with suppression of the commission of an offence in maritime zones and not specifically at ports, which invariably makes it impossible for the Malaysian Maritime Enforcement Agency (MMEA) to enforce the law. ${ }^{38}$ It is argued that MMEA

$36 \quad$ Irwin U.J. Ooi, "The Malaysian Maritime Enforcement Agency Act 2004: Malaysia's Legal Response to the Threat of Maritime Terrorism," Australian \& New Zealand Maritime Law Journal, 21 (2007): 75. See also Zulkifli Bin Abu Bakar, "Strengthening Comprehensive and Cooperative Security in the Asia Pacific: Enhancing Maritime Security - Law Enforcement in Malaysia." Institute of Strategic and International Studies (ISIS), accessed November 27, 2012, www.isis.org.my/files/24APRWEB/Zulkifli_Abu_Bakar.pdf.

$37 \quad$ Ibid.

38 For a better appreciation of this argument, see the long title to this 
Act will achieve its main objective of maintaining law and order at maritime zones if its enforcement starts from ports, because ports are the routes for all maritime security threats.

3. It has also been observed that the principle of hot pursuit in the case of wanton discharge of oil by ships, which is an established practice under customary international law in article 111 of the 1982 UNCLOS, is not included under the MMEA Act. The right of hot pursuit can be exercised by the MMEA where a foreign ship violates national laws such as the MMEA Act that are applicable in the Exclusive Economic Zone, Contiguous Zone, and Territorial sea. If the provision is made in the Act, the MMEA would have the right as an agency of a coastal state to pursue foreign flagged ships that violate Malaysian national laws through the high seas. ${ }^{39}$ Therefore, in case of violations such as indiscriminate discharge of oil, importation of prohibited goods, firearms, bombs, etc. by foreign ships that culminate in hot pursuit, the MMEA as well as the prosecutor would be able to refer to national law that a foreign ship had breached without necessarily referring to international convention. ${ }^{40}$ It has however been asserted that MMEA lacks an adequate mechanism for the right of hot pursuit in case of indiscriminate discharge of oil by ships, because its Bombardier 415 multi-purpose amphibious aircraft

enactment which is very specific on the area of operation of the agency, the maritime zone of Malaysia.

39 Hamid Abdul Ghafur, Public International Law: A Practical Approach, $3^{\text {rd }}$ ed. (Kuala Lumpur: Sweet and Maxwell Asia, Thompson Reuter, 2011), 285. See also Malcolm Evans, "The Law of the Sea," in International Law, ed. Malcolm Evans (New York: Oxford University Press, 2010), 667-668. See the case of M/V Saiga No. 2 (St Vincent and the Grenadines $v$ Guinea) of $1^{\text {st }}$ July, 1999 where the International Tribunal on the Law of the Sea (ITLOS) emphasised the need for a stringent approach to be taken with respect to Article 111 of the UNCLOS 1982. to the Protection of the Marine Environment in Malaysia" (report submitted to the Law Reform Committee, Prime Minister's Department, Malaysia, October 15, 2011), 53-54. 
that detects oil slicks at sea, cannot stop ships causing oil slicks as its activities could be disturbed by weather. ${ }^{41}$ In addition, there is need for continuous training of the MMEA officers, as otherwise the purchase of more or stronger aircraft may not yield any positive result. ${ }^{42}$

4. The MMEA Act is silent on the qualification of a civil servant to be appointed as the Director General of the MMEA. It is obvious that ensuring port security is one of the ways of protecting national security, and for this reason, appointment of competent personnel as MMEA members will be conducive to a safe port. Knowledge of ports, pollution and maritime security affairs should be an essential qualification for appointment as the Director-General of the MMEA. Since the MMEA is now the sole agency for maritime enforcement in Malaysia, this gap needs to be addressed by inserting a provision in the MMEA Act, allowing only civil servants with the requisite knowledge of ports, pollution, and maritime security be appointed as the Director General. Where a Director-General who is not knowledgeable in ports, pollution and maritime security is appointed to manage maritime affairs, he may lack the ability to control, direct and manage the officers of the MMEA as well as the other security agencies involved at border ports. Accordingly, there is need for a provision under the MMEA Act that will make it obligatory for the Director General of the MMEA to have a military background.

\section{CONCLUSION}

It was observed in this paper that the general scheme of the Environmental Quality Act is not geared towards prevention of environmental pollution, but is control oriented. Therefore, to achieve the main objective of the

\footnotetext{
K1 Kasmin Sutarji, at 63

42 As similar view was expressed concerning the Australia Navy. See Andrew Gough, "ADF Amphibious Capacity: Implications for Navy," in Australian Maritime Issues 2005, eds. Gregory P. Gilbert and Robert J. Davitt (Canberra: Sea Power Centre, 2005), 63.
} 
Act in preventing oil spillage by ships, there is a need for an adequate enforcement mechanism. This paper also recommends that for the MMEA to achieve its mandate as the sole maritime enforcement agency in Malaysia, appointment of a qualified person as the head of the agency should be ensured. It is also the position of this paper that the maximum penalty imposed for wanton discharge of oil is unreasonable, compared with what is imposed in Singapore. Although it is argued that monetary penalty alone may not serve as a deterrent, increment in the penalty up to the level found in Singapore might be helpful. 